\title{
PENGARUH STRATEGI PERIKLANAN TERHADAP KEPUTUSAN MAHASISWA \\ (Studi Kasus Pada STIKes Pertamina Bina Medika Jakarta)
}

\author{
Kasmad *) \\ email:ng_kasmetro@yahoo.com \\ Udin Ahidin ${ }^{* \star}$ \\ Kiki Dwi Wijayanti ${ }^{\star \star \star}$ )
}

\begin{abstract}
ABSTRAK
Penelitian ini bertujuan untuk mengetahui Pengaruh Strategi Periklanan terhadap keputusan mahasiswa pada Sekolah Tinggi Ilmu Kesehatan Pertamina Bina Medika (STIKes Pertamedika) Jakarta.

Penelitian ini bersifat deskriptif asosiatif, Populasi dalam penelitian ini adalah mahasiswa program studi S1 dan D III keperawatan Semester 1 yang berjumlah 140 orang dengan teknik sampling secara acak Stratified Random Sampling yaitu dengan cara mengambil sample dengan memperhatikan strata (tingkatan) di dalam populasi serta menggunakan table Isaac dan Michael dalam menentukan sampel. Adapun sampel dalam penelitian sebanyak 100 orang. Pengumpulan data dengan menggunakan kuesioner data yang diperoleh dari kuesioner kemudian dianalisis menggunakan bantuan program Microsoft Excel dengan metode uji validitas, uji reliabilitas, koefisiensi korelasi, koefisiensi determinasi, dan uji hipotesis.

Terdapat pengaruh positif dan signifikan antara strategi periklanan $(X)$ terhadap keputusan mahasiswa $(Y)$ dengan nilai koefisiensi korelasi $(r)=0.858$. besarnya pengaruh atau kontribusi strategi periklanan $(X)$ terhadap keputusan mahasiswa $(\mathrm{Y})$ sebesar $73,62 \%$. Tingkat signifikansinya adalah signifikan $\mathrm{t}$ hitung $9,2326>\mathrm{t}$ tabel 1,984 , maka $\mathrm{H} 0$ ditolak dan $\mathrm{H} 1$ diterima, dengan demikian hipotesis dalam penelitian ini adalah terdapat pengaruh positif dan signifikan antara strategi periklanan $(\mathrm{X})$ terhadap keputusan mahasiswa $(\mathrm{Y})$ di STIKes Pertamina Bina Medika Jakarta.
\end{abstract}

Kata Kunci : Strategi Periklanan, Keputusan Mahasiswa

\section{ABSTRACT}

This study aims to determine the Influence of Advertising Strategy on student decisions at the School of Health Sciences Pertamina Bina Medika (STIKes Pertamedika) Jakarta.

This research is descriptive associative, The population in this study is the students of S1 and D III nursing program Semester 1 which amounted to 140 people with a random sampling technique Stratified Random Sampling is by taking samples with attention to strata (level) in the population and using a table Isaac and Michael in determining the sample. The sample in the study of 100 people. Data collection using questionnaire data obtained from the questionnaire was then analyzed using the help of Microsoft Excel program with validity test method, reliability test, correlation coefficient, determination coefficient, and hypothesis test.

There is a positive and significant influence between advertising strategy $(X)$ on student decisions $(Y)$ with correlation coefficient value $(r)=0.858$. the amount of influence or contribution of advertising strategy $(X)$ to student decision $(Y)$ equal to $73,62 \%$. The level of significance is significant $t$ arithmetic 9.2326> $t$ table 1.984, then $\mathrm{HO}$ rejected and $\mathrm{H} 1$ accepted, thus the hypothesis in this study is there a positive and significant influence between advertising strategy $(X)$ on student decisions ( $Y$ ) in STIKes Pertamina Bina Medika Jakarta.

Keywords: Advertising Strategy, Student Decision 


\section{A. Pendahuluan.}

Salah satu cara dalam menghadapi persaingan di era globalisasi adalah memiliki kemampuan secara akademis yang tinggi. Berkaitan dengan hal tersebut maka pendidikan merupakan hal penting bagi masyarakat agar mampu memenangkan persaingan tersebut. Untuk itu masyarakat dituntut untuk mampu memahami informasi di zaman persaingan yang semakin ketat, tentunya untuk memenuhi kebutuhan pendidikan masyarakat, kehadiran institusi pendidikan dinilai sangat penting untuk mendidik serta mempersiapkan masyarakat menjadi insan yang berilmu yang memiliki keahlian yang memadai

Namun dewasa ini, eksistensi Perguruan Tinggi Negeri tidak lagi menjadi pilihan utama bagi masyarakat khususnya calon mahasiswa, karena tren calon mahasiswa saat ini tidak hanya melihat positioning Perguruan Tinggi Negeri sebagai institusi pendidikan unggulan, andalan dan favorite sebagai satu - satunya pertimbangan untuk memutuskan melanjutkan pendidikan. Kehadiran Perguruan Tinggi Swasta dengan segala kelebihan yang diunggulkan bisa jadi membuat masyarakat menentukan untuk melanjutkan pendidikannya di institusi tersebut.

Perguruan Tinggi Swasta (PTS) merupakan salah satu organisasi sosial yang bergerak dalam bidang edukasi menuju penciptaan sumber daya manusia yang berkompeten dalam segala dimensi kehidupan. PTS sama halnya dengan Perguruan Tinggi Negri (PTN), berupaya untuk mengembangkan lembaga pendidikan yang maju dan berkualitas. Dari segi bisnis, kualitas dari sebuah perguruan tinggi menjadi daya tarik bagi masyarakat dan memberikan manfaat besar baik bagi mahasiswa maupun bagi tenaga-tenaga yang berada di dalam institusi pendidikan tersebut.

Dalam era globalisasi dan semakin semaraknya konsentrasi jurusan yang terdapat di banyaknya Perguruan Tinggi, Sekolah Perawat merupakan salah satu institusi pendidikan yang berorientasi penuh pada Tri Dharma Perguruan Tinggi, merupakan institusi bidang keahlian yang memberikan manfaat kepada para mahasiswa yang dapat mengaplikasikan ilmu yang didapatkan selama berkuliah pada kehidupan pribadi, serta keahlian khusus yang dimiliki mempermudah dalam mencari pekerjaan yang sesuai dengan konsentrasi bidang ilmu yang dijalani.

STIKes Pertamina Bina Medika hadir ditengah masyarakat, merupakan Institusi pendidikan bidang keperawatan ysng berorientasi mencetak tenaga perawat siap pakai, dengan menjamin setiap lulusan untuk langsung bekerja, ini merupakan salah satu daya tarik yang bisa menjadi pilihan bagi masyarakat khususnya para calon mahasiswa yang merupakan lulusan dari tingkat SMA/Sederajat.

Pemasaran sering dikaitkan dengan dunia bisnis. Hal ini wajar karena kata pemasaran atau istilah marketing tersebut seringkali muncul dan berkembang di kalangan bisnis, baik bisnis jasa maupun bisnis manufaktur. Lalu, timbul pertanyaan apakah perlu memasarkan sekolah ?

Salah satu kegiatan pemasaran yang dilakukan oleh STIKes Pertamedika adalah kegiatan periklanan, suatu perusahaan diharapkan dapat mengkomunikasikan atau menyampaikan informasi produknya kepada konsumen dan dapat pula mengevaluasi hasil dari kegiatan komunikasi pemasaran melalui iklan ini, atas dasar itulah maka perusahaan dapat mengetahui apakah periklanan cukup efektif dalam menarik minat masyarakat untuk memutuskan melanjutkan 
perkuliahan di STIKes Pertamedika. Periklanan dapat memberikan peluang yang sangat besar terhadap kepentingan kedua belah pihak. Perushaan berkepentingan bahwa produk yang ditawarkan dapat diketahui konsumen melalui iklan yang dilakukan sedangkan para konsumen dapat mengetahui informasi yang sesuai kebutuhannya melalui iklan tersebut sehingga dapat terlihat jelas pengaruh periklanan terhadap keputusan peminatan mahasiswa baru STIKes Pertamedika.

Jumlah mahasiswa STIKes Pertamedika mengalami penurunan dan tidak stabil, terlihat dari diagram penerimaan mahasiswa baru yang selalu mengalami perubahan.

Faktor yang mempengaruhi fluktuasi jumlah mahasiswa adalah kurangnya tenaga pemasar yang membuat kegiatan pemasaran tidak dapat dilaksanakan secara efektif, selanjutnya dari segi tempat / lokasi, dikarenakan STIKes Pertamedika belum memiliki gedung perkuliahaan sendiri sehingga menyulitkan tenaga pemasar untuk mencapai hasil yang maksimal, karena dengan lokasi yang berpindah pindah tentunya akan berdampak pada biaya operasional dan promosi yang cukup tinggi, faktor selanjutnya adalah dari strategi promosi, penerapan strategi promosi STIKes Pertamedika juga masih kurang optimal dikarenakan belum maksimal memanfaatkan strategi periklanan yang seharusnya menjadi modal utama dalam mempengaruhi keputusan mahasiswa untuk melanjutkan pendidikan ke STIKes Pertamedika.

Strategi periklanan yang selama ini dilakukan oleh STIKes Pertamedika memang terlihat masih "tanggung" karena belum berani mencoba ke ranah media elektronik dikarenakan besarnya biaya periklanan yang dibutuhkan, itulah yang menjadi salah satu kesulitan STIKes Pertamedika untuk mempengarhi keputusan mahasiswa baru dala peminatan ke STIKes Pertamedika.

Dengan latar belakang ingin mengetahui bagaimana pengaruh strategi periklanan terhadap Keputusan mahasiswa pada Institusi Pendidikan STIKes Pertamedika, maka penulis menuangkannya dalam bentuk skripsi dengan Judul "Pengaruh strategi periklanan terhadap Keputusan Mahasiswa (Studi Kasus Pada STIKes Pertamedika Jakarta"

\section{B. Perumusan Masalah}

Berpangkal dari latar belakang masalah seperti yang telah diuraikan diatas, Perumusan masalah sebagai berikut :

1. Bagaimana pengaruh strategi periklanan terhadap keputusan mahasiswa pada STIKes Pertamedika?

\section{Tujuan Penelitian}

Adapun tujau penelitian ini adalah :

1. Untuk mengetahui pengaruh strategi periklanan terhadap keputusan mahasiswa pada STIKes Pertamedika.

\section{Landasan Teori}


Manajemen adalah kosa kata yang berasal daru Bahasa Perancis kuno, yaitu menegement yang berarti seni melaksanakan dan mengatur. Sejauh ini memang belum ada kata yang mapan dan diterima secara universal sehingga pengertiannya untuk masing-masing para ahli masih memiliki banyak perbedaan.

Definisi lain menururt Richard L. Daft (2002:8), manajemen adalah pencapaian sasaran-sasaran organisasi dengan cara yang efektif dan efisien melalui perencanaan pengorganisasian, kepemimpinan, dan pengendalian sumber daya organisasi.

Dari beberapa definisi diatas dapat disimpulkan manajemen adalah mengatur untuk pencapaian sasaran-sasaran organisasi dengan cara efektif dan efisien untuk mencapai suatu tujuan.

Menurut Adrian Payne (2000:27) pemasaran merupakan suatu proses mempersepsikan, memahami, menstimulasi dan memenuhi kebutuhan pasar sasaran yang dipilih secara khusus dengan menyalurkan sumber - sumber sebuah organisasi untuk memenuhi kebutuhan - kebutuhan tersebut.

Pendapat diatas diperjelas oleh Philip Kotler (Kotler Philip, 1997:8) adalah suatu proses sosial dan manajerial yang didalamnya individu dan kelompok mendapatkan apa yang mereka butuhkan dan inginkan dengan menciptakan, menawarkan dan mempertukarkan produk yang bernilai dengan pihak lain.

Dari kedua definisi tersebut dapat ditarik kesimpulan bahwa dalam pemasaran dapat terjadi karena :

1. Adanya kegiatan manusia.

2. Adanya penjual dan pembeli.

3. Adanya benda yang dipertukarkan.

4. Untuk memperlancar serta menyempurnakan pertukaran.

5. Untuk membuat keputusan dalam menentukan produk, pangsa pasar, harga dan promosinya.

Periklanan adalah penggunaan media untuk memberitahukan kepada konsumen tentang sesuatu dan mengajak mereka melakukan sesuatu. Dari mata seorang konsumen, iklan merupakan sumber informasi atau hanya bentuk hiburan, sedangkan dari pandangan sosial, iklan merupakan suatu bentuk jasa suatu kelompok masyarakat. Secara umum iklan membantu menjelaskan akan suatu produk, sedangkan bagi perusahaan, iklan merupakan alat pemasaran yang sangat penting.

Lain halnya dengan pendapat Kotler yang dikutip oleh Bilson Simamora (2003:305). "Periklanan adalah segala bentuk presentasi non-personal suatu produk yang dibayar dan disponsori oleh sponsor yang jelas."

Dari definisi diatas dapat ditarik kesimpulan bahwa ada empat karakteristik iklan yaitu :

1. Pesan bersifat verbal, dapat didengar maupun visual.

2. Sponsor dapat diidentifikasi.

3. Diluncurkan melalui satu atau beberapa media.

4. Sponsor membayar media yang menampilkan iklan tersebut.

Menurut Lamb, Hair, Mc Daniel (2001:18) perilaku konsumen menggambarkan bagaimana konsumen membuat keputusan-keputusan pembelian dan bagaimana mereka menggunakan dan mengatur pembelian barang atau jasa.pelajaran 
mengenai perilaku konsumen juga menyangkut analisa faktor-faktor yang mempengaruhi keputusan pembelian dan penggunaan produk.

Menurut Mangkunegara $(2005,4)$ perilaku konsumen adalah tindakan-tindakan yang dilakukan oleh individu, kelompok atau organisasi yang berhubungan dengan proses pengambilan keputusan dalam mendapatkan, menggunakan barang-barang atau jasa ekonomis yang dapat dipengaruhi lingkungan.

Dari pengertian diatas dapat disimpulkan bahwa perilaku konsumen adalah tindakan -tindakan individu atau konsumen dalam proses membeli suatu barang atau jasa berdasarkan kebutuhan yang akan berdampak pada proses pengambilan keputusan konsumen.

Proses pengambilan keputusan merupakan serangkaian aktivitas mental dan fisik yang dilakukan oleh konsumen sebelum terjadi pembelian aktual (Ferrinadewi dan Darmawan, 2004:13). Pertanyaan yang perlu mendapat jawaban dalam proses ini adalah apakah pembelian perlu dilakukan atau tidak, mengapa perlu melakukan pembelian, dimana dan bagaimana akan melakukan pembelian, seberapa banyak dan sering pembelian akan dilakukan melalui serangkaian tahap yang dimulai dari pengenalan masalah, pencarian informasi, pemrosesan informasi, evaluasi alternative dan keputusan pembelian.

\section{E. Metodologi}

Populasi dalam penelitian ini adalah jumlah seluruh mahasiswa STIKes Pertamedika pada tingkat I Program Studi D.III dan S1 Keperawatan sebanyak 140 Orang. Teknik pengambilan sampel menggunakan Stratified Random Sampling. Stratified Random Sampling adalah cara mengambil sample dengan memperhatikan strata (tingkatan) di dalam populasi. Dalam stratified data sebelumnya dikelompokan kedalam tingkat-tingkatan tertentu, seperti : tingkatan tinggi, rendah, sedang/baik, jenjang pendidikan kemudian sample diambil dari tiap tingkatan tersebut. (Sugiyono 2011:64) Adapun sampel dalam penelitian sebanya 95 orang.

Penelitian dilakukan di Sekolah Tinggi IImu Kesehatan Pertamina Bina Medika yang berlokasi di Jalan Bintaro Raya No.10, Tanah Kusir Kebayoran Lama Utara, Jakarta Selatan 12240, No. Telp : 021 - 7207184 / 021 - 7234122, fax : 021 7234126

Teknik yang digunakan dalam pengumpulan data dan informasi untuk pencapaian tujuan penelitian ini adalah (Mc. Leod dalam Husein Umar, 1999:41) :

Riset Kepustakaan (Library Research) riset yang dilakukan adalah dengan membaca dan mempelajari berbagai referensi, buku serta literatur yang berhubungan dengan strategi periklanan dan volume penjualan (Husein Umar, 1999:30).

Riset Lapangan (Field Research) penulis melakukan peninjauan langsung (direct observation) pada Sekolah Tinggi IImu Kesehatan Pertamedika Jakarta, dimana penulis mengamati, mencatatat serta melakukan pengambilan data primer dan data sekunder dari Perusahaan dengan metode sebagai berikut (Husein Umar, 1999:45) :

Wawancara (Interview) penulis melakukan wawancara penelitian dengan bertanya langsung kepada pihak terkait, terutama dengan Ketua STIKes Pertamedika Jakarta, dengan menggunakan pedoman wawancara terbuka. Wawancara digunakan untuk mendapatkan data tentang sejarah berdirinya STIKes 
Pertamedika, Struktur Organisasi, Jumlah Dosen, Jumlah Mahasiswa, dan Tenaga Pendidikan, Letak dan Unit-unit Pendidikan apa saja yang digunakan serta bagaimana proses periklanan yang dilakukan dalam meningkatkan jumlah mahasiswa dan apa saja yang telah dilakukan.

Kuesioner (Angket) Kuesioner adalah teknik pengambilan data yang dilakukan dengan memberi seperangkat pertanyaan atau pernyataa tertulis yang bertujuan untuk mengetahui informasi dari responden dengan menggunakan Skoring penilaian tertentu, seperti : Sangat Setuju $=5$, Setuju $=4$, Ragu-ragu $=3$, Tidak Setuju $=2$, Sangat Tidak Setuju = 1. (Husein Umar, 1999:52)

Observasi, Observasi merupakan teknik pengumpulan data, dimana peneliti melakukan pengamatan secara langsung ke objek penelitian untuk melihat dari dekat kegiatan yang dilakukan (Ridwan, 2004 : 104).

Uji validitas instrument, menunjukkan sejauh mana suatu alat pengukur dapat dipercaya, uji validitas instrument dalam penelitian ini peneliti menggunakan rumus korelasi product moment. Adapun korelasi produk momen pearson adalah sebagai berikut :

$$
\mathrm{rx}_{\mathrm{i}} \mathrm{X}_{\mathrm{t}}=\frac{\mathrm{n}\left(\sum \mathrm{X}_{\mathrm{i}} \cdot \mathrm{X}_{\mathrm{t}}\right)-\left(\sum \mathrm{X}_{\mathrm{i}}\right) \cdot\left(\sum \mathrm{X}_{\mathrm{t}}\right)}{\sqrt{\left(\mathrm{n}\left(\sum \mathrm{X}^{2}\right)-\left(\sum \mathrm{X}^{2}\right)\left(\mathrm{n}\left(\sum \mathrm{X}_{\mathrm{t}}{ }^{2}\right)-\left(\sum \mathrm{X}_{\mathrm{t}}\right)^{2}\right)\right.}}
$$

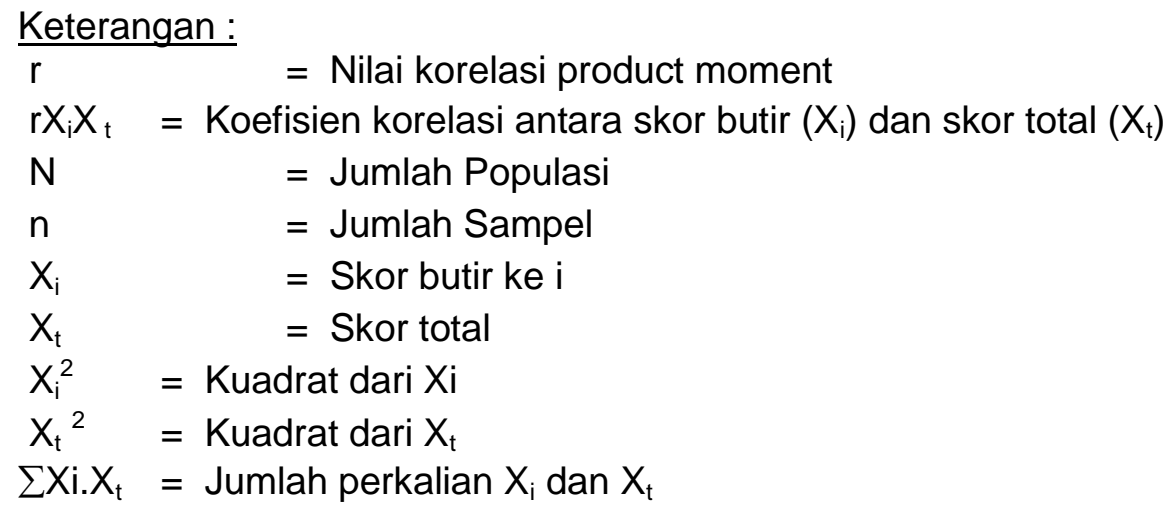

Uji reliabilitas variabel adalah serangkaian pengukuran yang memiliki konsistensi bila pengukuran dilakukan secara berulang yakni sejauh mana suatu tes dapat dipercaya untuk menghasilkan skor yang ajeg, relatif tidak berubah walaupun digunakan pada unit penelitian yang berbeda. Adapun rumus uji reliabilitas adalah :

$$
\text { rit }=\frac{\mathrm{k}}{\mathrm{k}-1}\left[\frac{\mathrm{St}^{2}-\Sigma \mathrm{Si}^{2}}{\mathrm{St}^{2}}\right]
$$

\section{Keterangan :}

$$
\begin{array}{ll}
\text { rit } & =\text { koefisien reliabilitas } \\
\mathrm{k} & =\text { banyaknya butir (butir yang valid saja) } \\
\mathrm{St}^{2} & =\text { varian skor total } \\
\boldsymbol{\Sigma} \mathrm{Si}^{2} & =\text { jumlah varian tiap butir }
\end{array}
$$


Uji Korelasi digunakan untuk melihat ada tidaknya hubungan antara variabel $X$ dan variabel Y. Adapun standar interval koefisiensi penilaian dapat dilihat pada table 1 di bawah ini.

Tabel 1 : Standar Interval Koefisiensi

\begin{tabular}{|l|l|}
\hline Interval Koefisien & Tingkat Hubungan / Pengaruh \\
\hline $0,00-0,19$ & Sangat Rendah \\
\hline $0,20-0,39$ & Rendah \\
\hline $0,40-0,59$ & Sedang \\
\hline $0,60-0,79$ & Kuat \\
\hline $0,80-1,00$ & Sangat Kuat \\
\hline
\end{tabular}

Sumber : Sugiyono (2008: 183)

Uji Hipotesis digunakan untuk mengukur seberapa besar pengaruh dan tingkat signifikansi variabel bebas $(\mathrm{X})$ terhadap variabel terikat $(\mathrm{Y})$

$\mathrm{H}_{\mathrm{o}}=0$ tidak ada pengaruh antara variabel $\mathrm{X}$ terhadap variabel $\mathrm{Y}$

$\mathrm{H}_{1} \neq 0$ ada pengaruh antara variabel $X$ terhadap variabel $Y$

\section{F. Hasil dan Pembahasan}

Uji validitas strategi periklanan

Tabel 2 : Ringkasan data kuesioner strategi periklanan

\begin{tabular}{|c|c|c|c|c|c|}
\hline No & $\mathbf{X i}$ & $\mathbf{X t}$ & $\mathbf{X}^{\mathbf{2}}$ & $\mathbf{X t}^{\mathbf{2}}$ & $\mathbf{X i . X t}$ \\
\hline$\Sigma$ & 322 & 3153 & 1142 & 106487 & 10867 \\
\hline
\end{tabular}

Sumber : Hasil Kuesioner diolah

$$
\begin{aligned}
& =\frac{1086700-1015266}{\sqrt{114200-103684} \sqrt{10648700-9941409}} \\
& r=\frac{100 \cdot 10867-(322) \cdot(3153)}{\sqrt{100 \cdot 1142-(322)^{2} \cdot} \sqrt{100.106487-(3153)^{2}}}
\end{aligned}
$$

$$
=\frac{71434}{\sqrt{10516} \sqrt{707291}}
$$

$$
\begin{aligned}
& =\frac{71434}{\sqrt{7437872156}} \\
& =\frac{71434}{86243,099}=0,828
\end{aligned}
$$

Untuk uji instrument yang lain dengan rumus yang sama semua instrument dinyatakan valid, adapun hasil uji validitas variabel strategi periklanan disampaikan pada table di bawah ini : 
Tabel 3 : Tabel Validitas Strategi Periklanan

\begin{tabular}{|c|c|c|c|}
\hline No. Instrumen & Perhitungan & Standar & Keterangan \\
\hline 1 & 0,828 & 0,197 & Valid \\
\hline 2 & 0,841 & 0,197 & Valid \\
\hline 3 & 0,723 & 0,197 & Valid \\
\hline 4 & 0,841 & 0,197 & Valid \\
\hline 5 & 0,879 & 0,197 & Valid \\
\hline 6 & 0,866 & 0,197 & Valid \\
\hline 7 & 0,869 & 0,197 & Valid \\
\hline 8 & 0,857 & 0,197 & Valid \\
\hline 9 & 0,867 & 0,197 & Valid \\
\hline 10 & 0,825 & 0,197 & Valid \\
\hline
\end{tabular}

Sumber : Hasil Kuesioner dioleh

Uji validitas variabel keputusan mahasiswa

Tabel 4 : Ringkasan hasil kuesioner keputusan mahasiswa

\begin{tabular}{|c|c|c|c|c|c|}
\hline No & $\mathbf{X i}$ & $\mathbf{X t}$ & $\mathbf{X}^{\mathbf{2}}$ & $\mathbf{X t}^{\mathbf{2}}$ & $\mathbf{X i .} \mathbf{X t}$ \\
\hline$\Sigma$ & 368 & 3253 & 1438 & 111775 & 12500 \\
\hline
\end{tabular}

Sumber : Hasil Kuesioner dioleh

$$
\begin{aligned}
& =\frac{100 \cdot 12500-(368) \cdot(3253)}{\sqrt{100 \cdot 1438-(368)^{2} \cdot} \sqrt{100 \cdot 111775-(3253)^{2}}} \\
& =\frac{1250000-1197104}{\sqrt{143800-135424 \cdot} \sqrt{11177500-10582009}} \\
& =\frac{52896}{\sqrt{8376} \sqrt{595491}} \\
& =\frac{52896}{\sqrt{4987832616}} \\
& =\frac{52896}{70624,59}=0,749
\end{aligned}
$$

untuk uji instrument yang lain dengan rumus yang sama semua instrument dinyatakan valid, adapun hasil uji validitas variabel keputusan mahasiswa adalah sebagai berikut : 
Tabel 5 : Tabel validitas instrmen keputusan mahasiswa

\begin{tabular}{|c|c|c|c|}
\hline No. Instrumen & Perhitungan & Standar & Keterangan \\
\hline 1 & 0.749 & 0,197 & Valid \\
\hline 2 & 0.637 & 0,197 & Valid \\
\hline 3 & 0.678 & 0,197 & Valid \\
\hline 4 & 0.831 & 0,197 & Valid \\
\hline 5 & 0.772 & 0,197 & Valid \\
\hline 6 & 0.698 & 0,197 & Valid \\
\hline 7 & 0.764 & 0,197 & Valid \\
\hline 8 & 0.837 & 0,197 & Valid \\
\hline 9 & 0.816 & 0,197 & Valid \\
\hline 10 & 0.887 & 0,197 & Valid \\
\hline
\end{tabular}

Sumber : Hasil Kuesioner diolah

Uji Reliabilitas Variabel strategi periklanan

$$
\begin{aligned}
& \mathrm{K}=10 \quad \text { Banyaknya Pernyataan } \\
& \sigma \mathrm{i}^{2}=10.125 \quad \text { Varian butir pernyataan yang dicari } \\
& \sigma \mathrm{t}^{2}=70.729 \quad \text { Total Varian pernyataan yang dicari } \\
& r c a=\left(\frac{k}{k-1}\right) \cdot\left(1-\frac{\sum S_{1}}{S_{t}}\right) \\
& r c a=\left(\frac{10}{10-1}\right) \cdot\left(1-\frac{10,125}{70,729}\right) \\
& r c a=\left(\frac{10}{9}\right) \cdot(1-0,143) \\
& r c a=1,111 \cdot 0,857 \\
& =0,952
\end{aligned}
$$

Uji reliabilitas variabel keputusan mahasiswa

$$
\begin{array}{lll}
\mathrm{K} & : 10 & \text { Banyaknya Pernyataan } \\
\sigma \mathrm{i}^{2} & : 10.17 & \text { Varian butir pernyataan yang dicari } \\
\sigma \mathrm{t}^{2} & : 59.55 & \text { Total Varian pernyataan yang dicari } \\
\mathrm{rca}=\left(\frac{k}{k-1}\right) \cdot\left(1-\frac{\sum s_{i}}{s_{t}}\right) \\
\left(\frac{10}{10-1}\right) \cdot\left(1-\frac{10.17}{59.55}\right) \\
\left(\frac{\mathbf{1 0}}{\mathbf{9}}\right) \cdot(\mathbf{1}-\mathbf{0 , 1 7})
\end{array}
$$$$
=1,111.0,83=0,922
$$ 
Tabel 6 : Uji Reliabilitas Variabel

\begin{tabular}{|c|c|c|c|}
\hline Variabel & Perhitungan & Standar & Keterangan \\
\hline Strategi Periklanan & 0,952 & 0,600 & Reliabel \\
\hline Keputusan Mahasiswa & 0,922 & 0,600 & Reliabel \\
\hline
\end{tabular}

Sumber : Hasil Kuesioner diolah

Pengaruh Strategi Periklanan Terhadap Keputusan Mahasiswa

Uji Korelasi

Selanjutnya peneliti mencari hasil uji korelasi untuk mengetahui besarnya pengaruh strategi periklanan $(\mathrm{X})$ terhadap keputusan mahasiswa $(\mathrm{Y})$.

Tabel 7 : Rekap hasil kuesioner

\begin{tabular}{|c|c|c|c|c|c|}
\hline No & $\mathbf{X t}$ & $\mathbf{Y t}$ & $\mathbf{X t}^{\mathbf{2}}$ & $\mathbf{Y t}^{\mathbf{2}}$ & $\mathbf{X t . Y t}$ \\
\hline$\Sigma=100$ & 3153 & 3253 & 106487 & 111775 & 108136 \\
\hline
\end{tabular}

Sumber : Hasil kuesioner diolah

$$
\begin{aligned}
& r x y=\frac{100.108136-(3153) \cdot(3253)}{\sqrt{100 \cdot 106487-(3153)^{2}} \cdot \sqrt{100 \cdot 111775-(3253)^{2}}} \\
& r x y=\frac{10813600-10256709}{\sqrt{10648700-9941409} \cdot \sqrt{11177500-10582009}}
\end{aligned}
$$

$$
\begin{aligned}
& r x y=\frac{556891}{\sqrt{707291} \cdot \sqrt{595491}} \\
& r x y=\frac{556891}{\sqrt{421185424881}} \\
& r x y=\frac{556891}{648988.0006}=0.858
\end{aligned}
$$

Setelah menginterpretasikan hasil korelasi yang didapat dengan tabel pedoman korelasi, ternyata $R_{x y} 0.858$ masuk kedalam interval sangat kuat, yang artinya terdapat pengaruh yang sangat kuat antara strategi periklanan $(X)$ terhadap keputusan mahasiswa (Y) pada STIKes Pertamina Bina Medika Jakarta.

Uji Determinasi $=K D=r^{2} \times 100 \%$

$$
\begin{aligned}
r^{2} & =0,858 \quad \text { Koefisien Korelasi } \\
\mathrm{KD}=0,858^{2} & \times 100 \% \\
= & 0,7362 \times 100 \% \\
= & 73,62 \%
\end{aligned}
$$


Hasil perhitungan menunjukkan bahwa t_hitung sebesar 9,2326, t_hitung 9,2326 > $\mathrm{t}$ _tabel 1,984 , maka $\mathrm{H}_{0}$ ditolak dan $\mathrm{H}_{1}$ diterima, dengan demikian hipotesis dalam penelitian ini adalah terdapat pengaruh yang positif dan signifikan antara strategi periklanan $(\mathrm{X})$ terhadap keputusan mahasiswa $(\mathrm{Y})$ di STIKes Pertamina Bina Medika Jakarta.

Kesimpulan terdapat pengaruh positif dan signifikan antara strategi periklanan terhadap keputusan mahasiswa dengan kontribusi pengaruh sebesar $73,62 \%$ dan tingkat signifikansinya 9,2326 > 1,984.

Manajemen STIKes Pertamina Bina Medika Jakarta perlu meningkatkan strategi periklanan untuk lebih meningkatkan calon mahasiswa yang mendaftar untuk menjadi mahasiswa/i di STIKes Pertamina Bina Medika Jakarta.

\section{G. Daftar Pustaka}

Abdullah, T, 2012, Manajemen Pemasaran, PT Rajagrafindo Persada, Jakarta Assauri, Sofjan, 2007, Manajemen Pemasaran, Rajawali Press, Jakarta

Buchari Alma, 2007, Manajemen Pemasaran dan Pemasaran Jasa, Alfabeta, Bandung

Christopher Lovelock, 2005, Manajemen Pemasaran Jasa, Kelompok Gramedia Indeks, Indonesia

Daft, Richard. L, 2002, Manajement, Edisi Kelima Jilid 1, Erlangga, Jakarta

Fajar Laksana, 2008, Manajemen Pemasaran, Pendekatan Praktis, Graha IImu, Yogyakarta

Gunawan Adisaputro, 2010, Manajemen Pemasaran, Analisis Untuk Perancangan Strategi Pemasaran, UPP STIM YKPN, Yogyakarta

Hasibuan, malayu S.P. 2002, Manajemen Dasar : Pengertian dan Masalah, Bumi Aksara, Jakarta

Kotler, Philip, 2002, Manajemen Pemasaran Edisi Millenium 2 (Diterjemahkan oleh Hendra dan Ronny A.Rusli) PT.Prenhalindo, Jakarta

Kotler, Philip, 2005, Manajemen Pemasaran Jilid 1 dan 2, PT.Indeks, Jakarta

Lewis, Pamela S. Stephen H. Goodman, Patricia M. Fondt, 2004, Management; Challenges For Tomorrow's Leader', McGraw Hill

Nasution, M.N, 2004, Manajemen Jasa Terpadu, PT. Ghalia Indonesia, Jakarta 
Rambat Lupiyoadi ddan A. Hamdani 2008, Manajemen Pemasaran Jasa, Salemba Empat, Jakarta

Rangkuti, Freddy, 2003, Riset Pemasaran, PT. Gramedia Pustaka Utama, Jakarta

Ratminto, 2006, Manajemen Pelayananm Pustaka Pelajar, Yogyakarta

Saladin, Djaslim, 2003, Intisari Pemasaran dan Unsur - Unsur Pemasaran, Cetakan Ketiga, Linda Karya, Bandung

Schiffman \& kanuk, 2004, Perilaku Konsumenm Edisi 7, Prentice Hall, Jakarta

Sofjan Assauri, 2009, Manajemen Pemasaran, Rajagrafindo Persada, Jakarta

Sunarto, 2006, Pengantar Manajemen Pemasaran, Penerbit : UST Press, Yogyakarta

Sugiono, 2012, Metode Penelitian Kuantitaif, Kualitatif dan RD, Alfabet, Bandung

Sugiono, 2010, Metode Penelitian Bisnis, Alfabet, Bandung

Sugiono, 2003, Statistik Untuk Penelitian, Alfabet, Bandung

Swasta, Basu, T, Hani Handoko, 2004, Manajemen Pemasaran : Analisa Perilaku Konsumen, Edisi Pertama Cetakan Ketiga, BPFE, Yogyakarta

Tjiptono, Fandy, 2008, Bauran Pemasaran Jasa, Bayu Media, Jawa Timur

Tjiptono, Fandy, 2008, Prinsip dan Dinamika Pemasaran, Edisi Pertama, Penerbit : J \& J Learning, Yogyakarta

Umar, Husein, 2003, Metodologi Penelitian Untuk Riset Skripsi dan Tesis Bisnis, Penerbit PT. Gramedia Pustaka Utama, Jakarta 